\title{
Phenology and Carbohydrate Metabolism of Japanese Pear Trees Grown under Continuously High Temperatures
}

\author{
Jaturaporn Rakngan, Hiroshi Gemma and Shuichi Iwahori \\ Institute of Agriculture and Forestry, University of Tsukuba, Tsukuba, Ibaraki 305
}

\begin{abstract}
Summary
The study was conducted for 3 consecutive years to evaluate the effect of continuous high temperature conditions on the performance of 6-year-old Japanese pear (Pyrus pyrifolia Nakai cv. Kosui). Under high temperature condition, the physiological characteristics of Japanese pear changed, namely, in the first year, pear trees that were transferred to a greenhouse in July and September were more vigorous than those transferred in November. During the autumn and spring, trees transferred in July did not accumulate sufficient chilling temperature, affecting the shoot growths in the later years; those transferred to the greenhouse in September had the shortest shoots compared to trees transferred in October and November. Trees which were transferred in November had earlier budbreak, better flower buds, flowered more uniformly, and set more fruit than did trees which were transferred in July and October. Furthermore, pollen grains from Treatment 3 ger. minated better than did those from trees in Treatment 1 and 2 . Similar results were obtained in 2nd and 3rd seasons.

Our analyses revealed that sugars increased in autumn just before dormancy while starch decreased. When the growth resumed in spring, starch increased and sugar de. creased. Trees transferred to the greenhouse later which received more chilling had a higher starch and sugar contents.
\end{abstract}

\section{Introduction}

The success of growing temperate fruit trees in the subtropical or tropical areas depends on many factors. These factors include internal and external ones such as those related to climate. Macroand microclimate which differ from those where the plants originated can cause different physiological changes. For example, temperate fruit trees grown under tropical and subtropical conditions resulted in weak plants (Subhadrabandhu, 1988). The most critical factor is the lack or deficiency of winter chilling required to break dormancy, leading to poor budbreak, bud drop, and poor foliage development, etc. (Erez, 1987). From whole leaf studies, it is established that photosynthesis is more temperature-sensitive than other physiological processes, i.e., respiration and ion uptake and transfer (Fitter and Hay, 1987).

Received for publication 11 September 1995.
Some of the physiological changes that affect phenological characteristics of Japanese pears grown under a heated plastic house are : 1) pear trees which receive enough chilling temperature and then grown in a heated house break dormancy earlier, resulting in early bloom and fruit set, leading to early harvest than trees receiving less chilling. 2) Heat treatment at the end of dormancy induces earlier flowering and fruit harvest (Gemma et al., 1990; Rakngan et al., 1995). These methods are widely used in fruit production in Japan, defined as "protected cultivation", because it in creases the incomes to the grower on account of earlier marketing and higher prices. However, the physiological changes in the trees grown under protected cultivation are not similar to those grown in adverse conditions such as in tropics and subtropics.

This study simulated the high temperature con dition of the tropics to understand poor growth and development of Japanese pear trees. 


\section{Materials and Methods}

The observation of phenological characteristics of pear trees grown under continuously high temperature exposed conditions

Twenty one 6-year-old Japanese pear (Pyrus pyrifolia Nakai cv. Kosui) were dug from a nursery on 13 March 1992 and transplanted into $65 \mathrm{~cm}$ black plastic containers containing a soil-compost mixture. They were severely pruned to an open center shape to minimize size. Shoots were bent to induce axillary shoot and spur formation. Fertiliz. ers were applied in late winter every year. The trees were divided into 3 groups referred to as Treatment 1,2 , and 3 . The experimental conditions and high temperature treatments were shown in Fig. 1.

The temperature inside the greenhouse was kept above $7.2{ }^{\circ} \mathrm{C}$ in winter and spring, to prevent the pear trees from being exposed to chilling tempera.

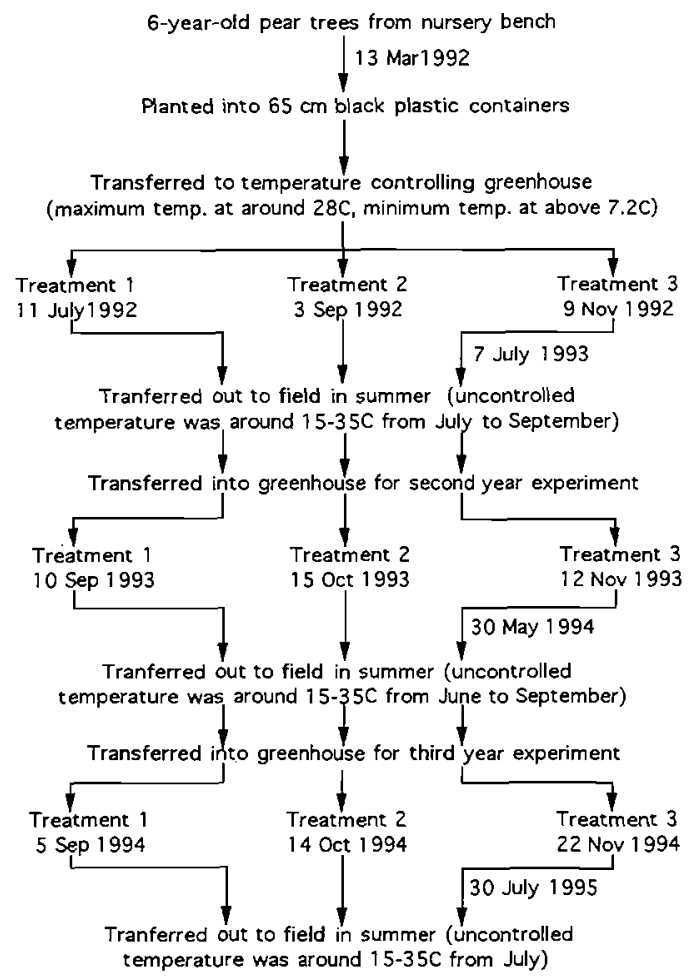

Fig. 1. Flow chart showing the experimental conditions and treatments from 1992 to 1995. ture, and around $28^{\circ} \mathrm{C}$ during the summer.

Phenological data obtained of the pear trees grown under 3 different temperature regimes were : 1) the number and length of new shoot per month, number of nodes and buds per shoot, the time of budbreak per tree, the number of total, leaf and flower buds, the percentages of leaf and flower budbreaks, and the number of fruit which set per tree after being pollinated with pollen of 'Chojuro'.

Pollen germination of Japanese pear flowers under high temperature conditions

Pollen germination of Japanese pear flower was evaluated for 3 seasons during flowering period as a criterion of the flower quality. Flowers at preblooming stage were collected from the greenhouse and from the open field and then kept under $28^{\circ} \mathrm{C}$ until pollen shed. The pollen was transferred to a medium consisting of $20 \%$ sucrose and $4 \%$ agar and incubated under light at $20{ }^{\circ} \mathrm{C}$ for 24 hours after which the number of germinated pollen was counted under a light microscope.

The carbohydrate analysis of Japanese pear trees grown under high temperature conditions

1. Sugar analysis: Shoot samples were collected every month from April 1993 through April 1995 , their buds excised, and stored at $-80{ }^{\circ} \mathrm{C}$ until used. Samples were blended in liquid nitrogen and a $2-\mathrm{g}$ aliquot extracted 3 times with $50 \mathrm{ml}$ of $80 \%$ ethanol. The ethanolic extracts were evaporated in vacuo at $40{ }^{\circ} \mathrm{C}$ to water phase and then passed through ion exchange resins (Amberlite IR-120B for cation and Amberlite IRA. 400 for anion); the residual protein was removed by $\mathrm{Ba}(\mathrm{OH})_{2}$ and $\mathrm{ZnSO}_{4}$. The filtrates were adjusted to $200 \mathrm{ml}$.

Twenty milliliters of sample extracts were dried on a hot plate and $1 \mathrm{ml}$ of $1,000 \mathrm{ppm}$ pentaerithritol was added as a internal standard for gas chromatograph (GC). The sample extracts were then put into $15 \mathrm{ml}$ vial and kept in a desiccator for over 2 days.

Trimethylsilane esterization was done by adding $1 \mathrm{ml}$ pyridine, $0.4 \mathrm{ml}$ hexamethyldisilazane (HMDS) and $0.4 \mathrm{ml}$ trimethylchlorosilane (TMCS) into the sample vial and heated. The samples were then injected into a gas chromatograph (Shimadzu GC-9AM), with Silicone GE SE-52 Chromosorb W (AW-DMCS) column and a flame ionization detec- 
tor (FID).

2. Starch analysis: To determine starch content, the sugar-free residue after ethanolic extraction was dried at $60^{\circ} \mathrm{C}$ for at least 3 days. A $0.5 \mathrm{~g}$ of dry samples was extracted with $20 \mathrm{ml}$ of $0.7 \mathrm{~N}$ $\mathrm{HCl}$ in a hot bath for 2.5 hours. The mixture was neutralized by titration with $0.1 \mathrm{~N} \mathrm{NaOH}$ and the protein was removed with $\mathrm{Ba}(\mathrm{OH})_{2}$ and $\mathrm{ZnSO}_{4}$. The volume of the resultant extracts was adjusted to $200 \mathrm{ml}$. For starch analysis, a $1 \cdot \mathrm{ml}$ sample was transferred into a test tube to which $6 \mathrm{ml}$ of anthrone reagent $(200 \mathrm{mg}$ of anthrone powder mixed with $95 \mathrm{ml}$ conc. $\mathrm{H}_{2} \mathrm{SO}_{4}$ and $5 \mathrm{ml}$ water in a cold water bath filled with ice) were added. The mixture was heated for 10 minutes at $98{ }^{\circ} \mathrm{C}$ in hot water and then cooled.

Starch in the sample was quantified by UV/VIS spectrophotometer (Jasco U best-35, Japan Spectroscopic Co., Ltd.) at $620 \mathrm{~nm}$ wavelength.

\section{Results}

The phenological changes of Japanese pear under high temperature condition

The shoot growth of pear trees was different among the treatments, in that trees which were moved into the greenhouse in July (Treatment 1) and September 1992 (Treatment 2) seem to be more vigorous during autumn, than were the trees which were moved into the greenhouse in Novem-

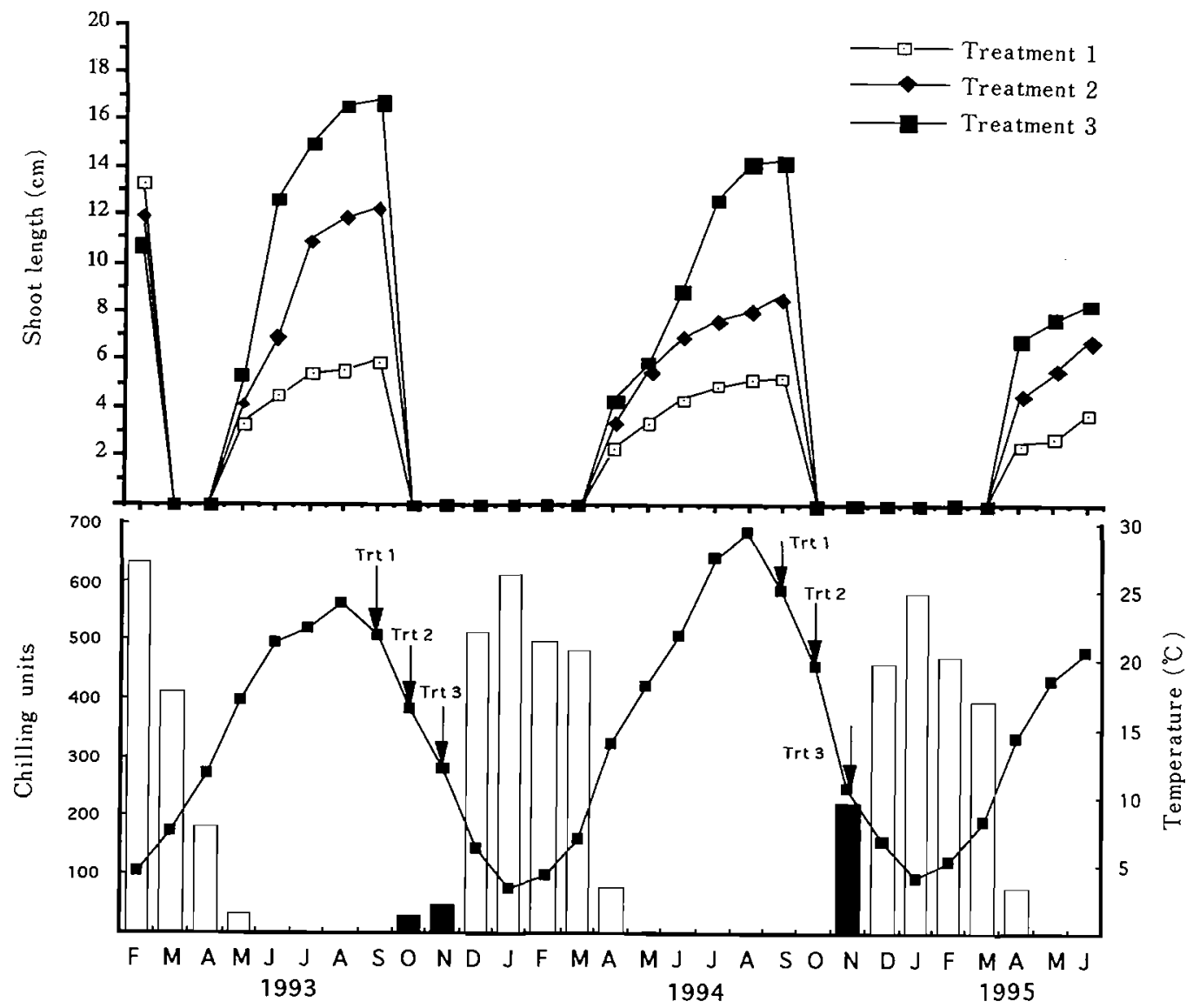

Fig. 2. Shoot length increased of different treatments in association with open field chilling units and average temperature.

- in the lower figure indicates average temperature of the open field.

Bar indicates chill units for each month from autumn to spring.

Arrow indicates the transferred times of each temperatures to the greenhouse. 
ber 1992 (Treatment 3) (Fig. 2). The increased vigor is attributed to the longer and warmer growth period greenhouse. When the new growth began in spring of 1993, however, shoots of the Treatment 1 were shortest, followed by Treatment 2. Trees of Treatment 3 that received longer, cool temperatures during the autumn in open field than did those of the other two treatments grew better than did those exposed to high summer temperature through September.

The effective temperature accumulation (ETA) summarizes the hours of favorable temperature to which fruit trees are exposed from spring through autumn; it seldom accumulates in winter. ETA was calculated by cumulating the number of hours above $10^{\circ} \mathrm{C}$ per day, the assumption being that below $10{ }^{\circ} \mathrm{C}$ growth did not occur. The data collected from 1992 to 1995 indicated that trees of three treatments were exposed to more favorable growing temperatures while in the greenhouse than did those in the open field. Between October and April, ETA of trees growing in the open field rapidly decreased to 0 unit during January and February; ETA then increased dramatically again from March to April. During the growing season from May to September when the trees were transferred back to the open field, the heat accumulation units increased even more (Fig. 4).

The difference in ETA among treatments affected growth and development of the trees. Treatment 1 trees received $12,022.78 \mathrm{hr}$ above $10{ }^{\circ} \mathrm{C}$ from January 1992 to June 1995 whereas those of Treatment 2 and 3 received $11,688.03$ and $11,037.5 \mathrm{hr}$, respectively. Those kept in the open field, only accumulated 7,389.2 hours (Fig. 4).

Thus, 1994, shoots grew the longest on trees in Treatment 3 followed by the Treatment 2 ; trees of the Treatment 1 which had 0 chill units had the poorest shoot growth. (An hour below $7.2{ }^{\circ} \mathrm{C}$ is equal to 1 chill unit (CU), Richardson et al., 1974). However, shoot growth in all the treatments in 1994 was less vigorous than it was in the previous year. The data on chilling temperatures among the treatments (Fig. 2) reveal that trees in Treatment 2 received about $30 \mathrm{CU}$, whereas those in Treatment 3 received $80.2 \mathrm{CU}$ (Figs. 2 and 3 ). In the fall of 1994, pear trees were again transferred to the greenhouse in September (Treatment 1), October (Treatment 2) and November (Treatment 3 ). Trees of Treatment 3 received $116.5 \mathrm{CU}$ units before being transferred to the greenhouse, whereas trees of Treatment 1 and 2 had received 0 CUs. Shoot growth indicates that the tree vigor was higher in Treatment 3 than were those the other treatments in 1995.

During 3 consecutive seasons, the shoot growth of trees in all treatments became shorter and shorter from 1993 to 1995 .

The three years data (Table 1) significantly show that flowering dates of Treatment 1 and 2 were significantly delayed as compared to Treatment 3 ; trees in Treatment 3 displayed a phenomenal full bloom. It was not the most desirable bloom because the flowering was straggly, extending from the middle of April to late May and even to 5 June in 1994. Trees in Treatment 2 also had an extended flowering period lasting from middle of April to late May while those in Treatment 1 flowered from late April or the beginning of May to the middle of June (Table 1 ).

The total bud breaks of Treatment 1 was significantly less than those of the other two treatments. Percentage of budbreak in Treatment 1 ranged from $54.0 \%$ to $67.9 \%$ in 3 years whereas in Treatment 2 and 3 , the ranges were 62.8 to $76.8 \%$ and 65.6 to $78.2 \%$, respectively. From 1993 to 1995 , trees exhibited delayed foliation and the percentages of budbreak in Treatment 1 , 2 , and 3 were $16.37,21.83$, and 25.63 , respectively. There were more flower buds produced in Treatment 2 and 3 than in Treatment 1 . Fruit set was highest in the Treatment 3 followed by the Treatment 2 and the least in Treatment 1 . The fruit set in 1995 was considerably higher than that in 1994 and 1993 (Table 1).

The pollen germination of Japanese pear under high temperature conditions

Pollen germination percentages were the highest in samples collected from the trees of Treatment 3 followed by those of Treatment 2 and 1 ; this pattern follows order of tree vigor as expressed by shoot length. Pollen germination in Treatment 1 dramatically decreased, from 1993 to 1995 , those Treatment 2 and 3 in 1994 were higher than those of 1993 and 1995. Although, Treatment 3 had the highest pollen germination as compared to the other two treatments, it was, nevertheless, considerably lower than that of the trees grown on open field (Fig. 5). 


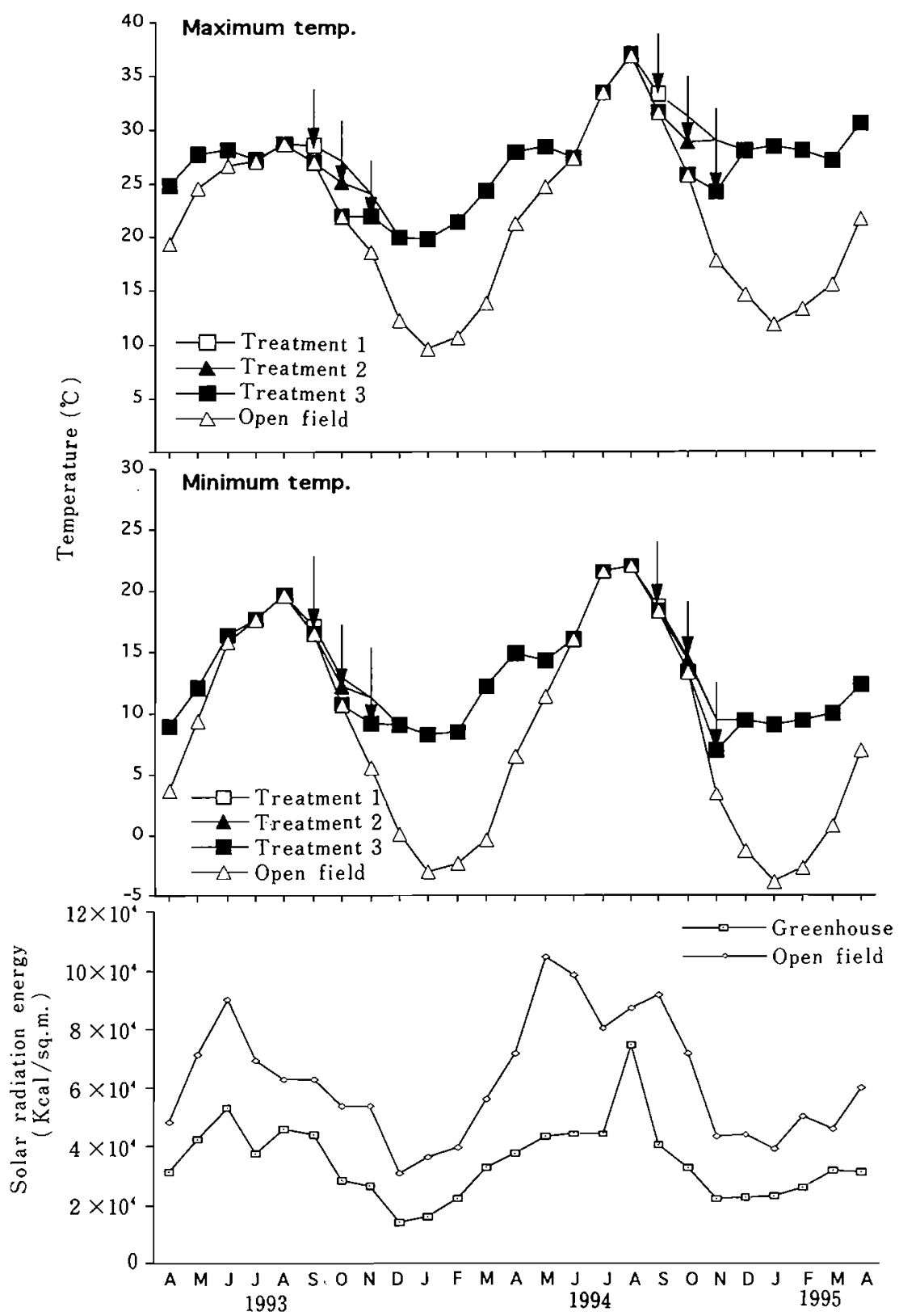

Fig. 3. Maximum and minimum temperatures perceived by trees in the three treatments and in the open field and the annual solar radiation from 1993 to 1995.

Arrows indicate the transferring times of different treatment of potted pear trees to the greenhouse.

Carbohydrate metabolisms during high temperature condition

Sorbitol is the major translocatable carbohy- drate in the pear tree shoots existing in the highest level during all the periods of growth. It is followed by glucose, fructose and sucrose. Starch which is most plentiful storage carbohydrate in 


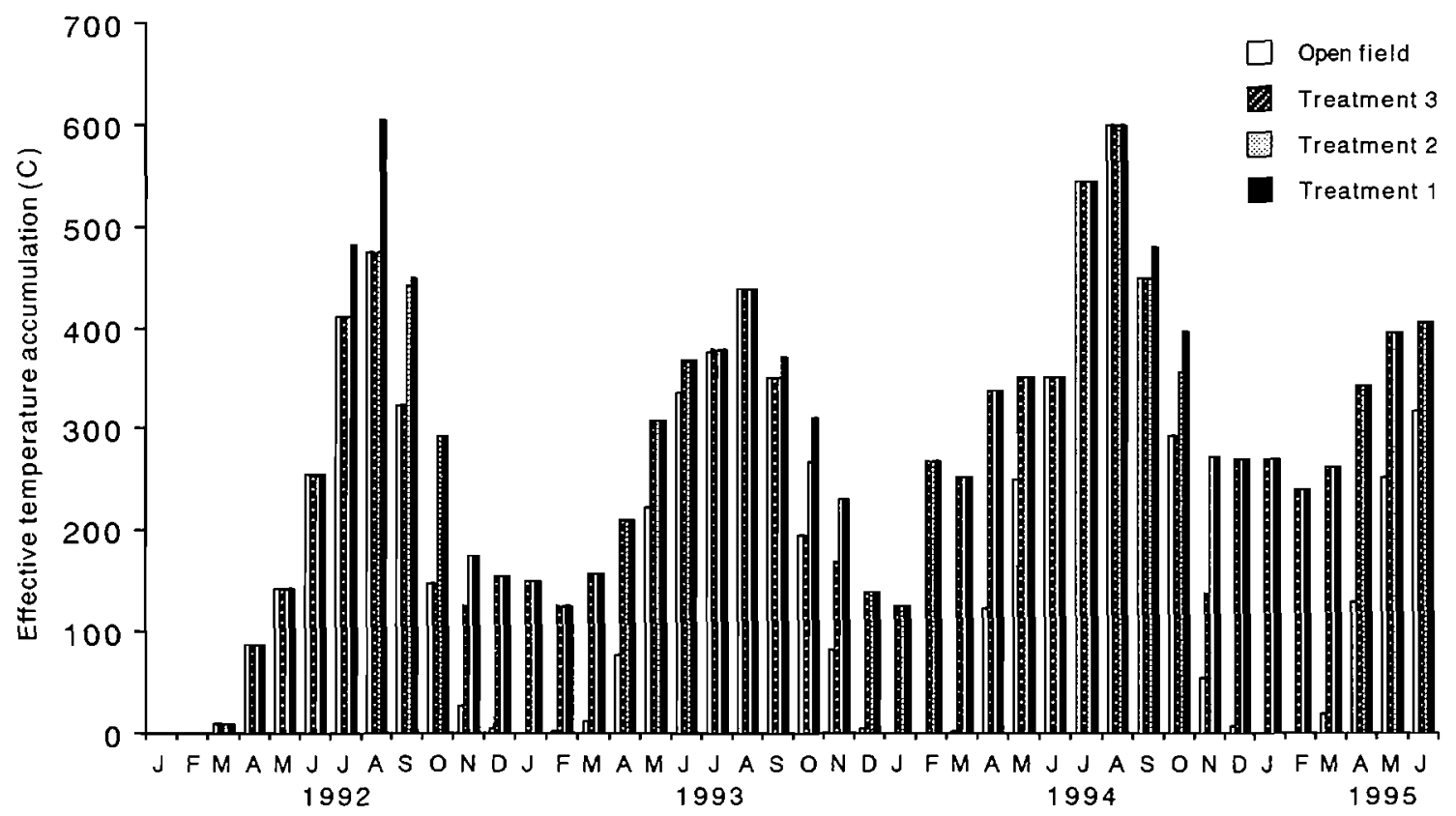

Fig. 4. Effective temperature accumulations by different pear treatments as compared to open field (data from 1992 to 1995).

Table 1. Bud break characteristics of pear grown under high temperature conditions (Data was collected from 1993 to 1955).

\begin{tabular}{|c|c|c|c|c|c|c|c|c|c|c|c|}
\hline \multirow{2}{*}{\multicolumn{2}{|c|}{ Treatment }} & \multirow{3}{*}{$\begin{array}{l}\text { Total } \\
\text { buds }\end{array}$} & \multirow{3}{*}{$\begin{array}{l}\begin{array}{l}\text { First date } \\
\text { of flower } \\
\text { break }\end{array} \\
\text { 6May93 }\end{array}$} & \multirow{3}{*}{$\begin{array}{l}\begin{array}{l}\text { Last date } \\
\text { of flower } \\
\text { break }\end{array} \\
\text { 4Jun93 }\end{array}$} & \multicolumn{2}{|c|}{ Total bud break } & \multicolumn{2}{|c|}{ Leaf bud break } & \multicolumn{2}{|c|}{$\begin{array}{l}\text { Flower bud } \\
\text { break }\end{array}$} & \multirow{3}{*}{$\begin{array}{l}\begin{array}{l}\text { Fruit } \\
\text { set } \\
(\%)\end{array} \\
4.40\end{array}$} \\
\hline & & & & & Number & $\%$ break & Number & \%break & Number & \%break & \\
\hline \multirow[t]{3}{*}{ TRT1 } & 93 year & & & & 112.40 & 66.20 & 94.70 & 55.80 & 17.70 & 10.40 & \\
\hline & 94 year & 133.33 & $18 \mathrm{Apr} 94$ & 14Jun94 & 72.00 & 54.00 & 43.00 & 32.25 & 29.00 & 21.75 & 7.67 \\
\hline & 95 year & 128.66 & 26Apr95 & 9Jun95 & 87.33 & 67.88 & 65.50 & 50.91 & 21.83 & 16.97 & 11.00 \\
\hline \multicolumn{2}{|l|}{ avg. } & $141.53 x$ & $\mathrm{y}$ & ns & & $62.66 \mathrm{x}$ & & $46.28 \mathrm{x}$ & & $16.37 x$ & $7.69 x$ \\
\hline \multirow[t]{3}{*}{ TRT2 } & 93 year & 184.70 & $23 \mathrm{Apr} 93$ & 28 May 93 & 133.70 & 72.40 & 104.60 & 56.60 & 28.00 & 15.20 & 7.00 \\
\hline & 94 year & 135.86 & 15 Apr 94 & 7Jun94 & 85.29 & 62.78 & 55.43 & 40.80 & 29.86 & 21.98 & 8.14 \\
\hline & 95year & 136.57 & $18 \mathrm{Apr} 95$ & 23 May 95 & 104.86 & 76.78 & 66.14 & 48.43 & 38.71 & 28.34 & 19.14 \\
\hline \multicolumn{2}{|l|}{ avg. } & $153.74 y$ & $\mathrm{x}$ & ns & & $70.57 y$ & & $48.61 \mathrm{y}$ & & $21.83 y$ & $11.48 \mathrm{y}$ \\
\hline \multirow[t]{3}{*}{ TRT3 } & 93 year & 147.10 & 23Apr93 & 28 May 93 & 116.00 & 78.90 & 83.90 & 57.00 & 32.10 & 21.80 & 9.60 \\
\hline & 94 year & 126.71 & 13Apr 94 & 5Jun94 & 83.14 & 65.61 & 48.00 & 37.88 & 35.14 & 27.73 & 8.43 \\
\hline & 95 year & 152.00 & 12Apr 95 & 23 May 95 & 118.86 & 78.20 & 86.42 & 56.86 & 41.57 & 27.35 & 17.14 \\
\hline \multicolumn{2}{|l|}{ avg. } & $144.38 \mathrm{x}$ & 2 & ns & & $73.93 z$ & & $50.58 z$ & & $25.63 z$ & 11.722 \\
\hline
\end{tabular}

Different letters within the average of a column show significant defference by Duncan's multiple range test at $\mathrm{p}=0.05$ (ns $=$ no significant difference).

$\%$ bud break $=$ percentage of bud break as compared to total bud numbers.

TRT $1=$ potted pear trees were moved into greenhouse on September.

TRT2 $=$ potted pear trees were moved into greenhouse on October.

$\mathrm{TRT} 3=$ potted pear trees were moved into greenhouse on November. 


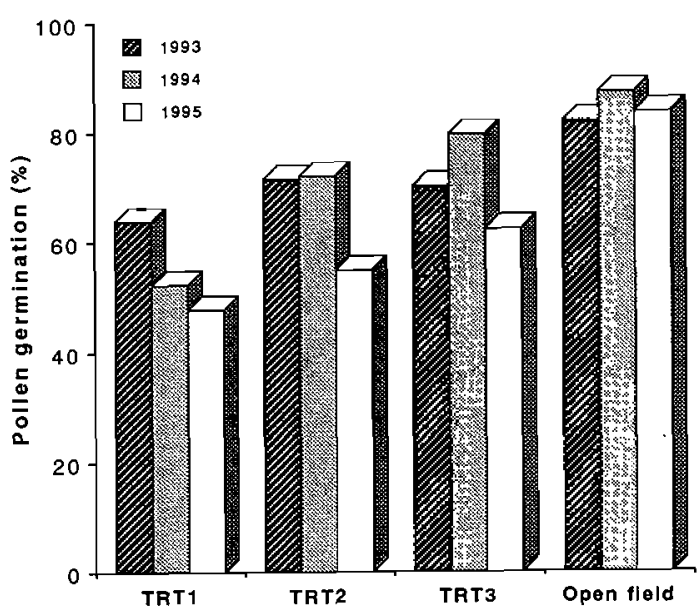

Fig. 5. Pollen germination of pear trees growing under high temperature conditions as compared to that in the open field. pear trees increased during the vegetative growth period; it hydrolyzed to glucose during the winter. During the period of high starch content, sugar contents, especially sorbitol, were low. The increase of sugar contents was found when pear trees entered rest. Generally, shoots of Treatment 3 were highest in sugar contents (Figs. 6 and 7 ). The changes of sugar contents in the shoots of all treatments were as follows; during September, glucose content was highest, whereas sorbitol and fructose levels were high in November; sucrose was the predominant sugar in December. Pattern of carbohydrate change from 1993 to 1995 was different in that trees exposed to high temperature for half a year, the carbohydrate metabolism changed among the treatments. In 1993, soluble carbohydrate and starch contents in Treatment 3 increased earlier followed by Treatment 2 and then Treatment 1 . In 1994, this pattern was some-

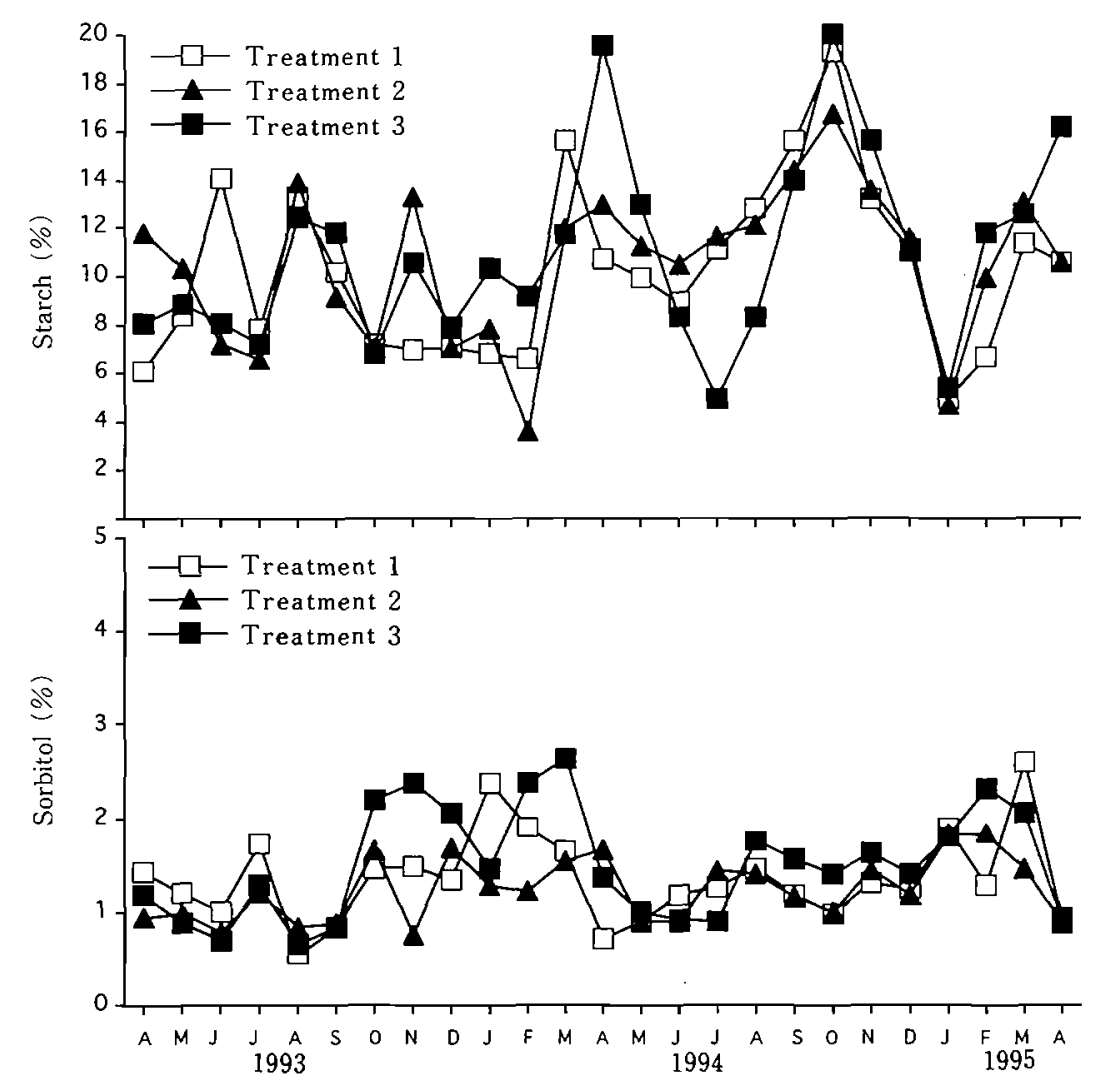

Fig. 6. Seasonal changes in starch and sorbitol content in shoot of Japanese pear trees grown under different treatments during 1993 to 1995. 


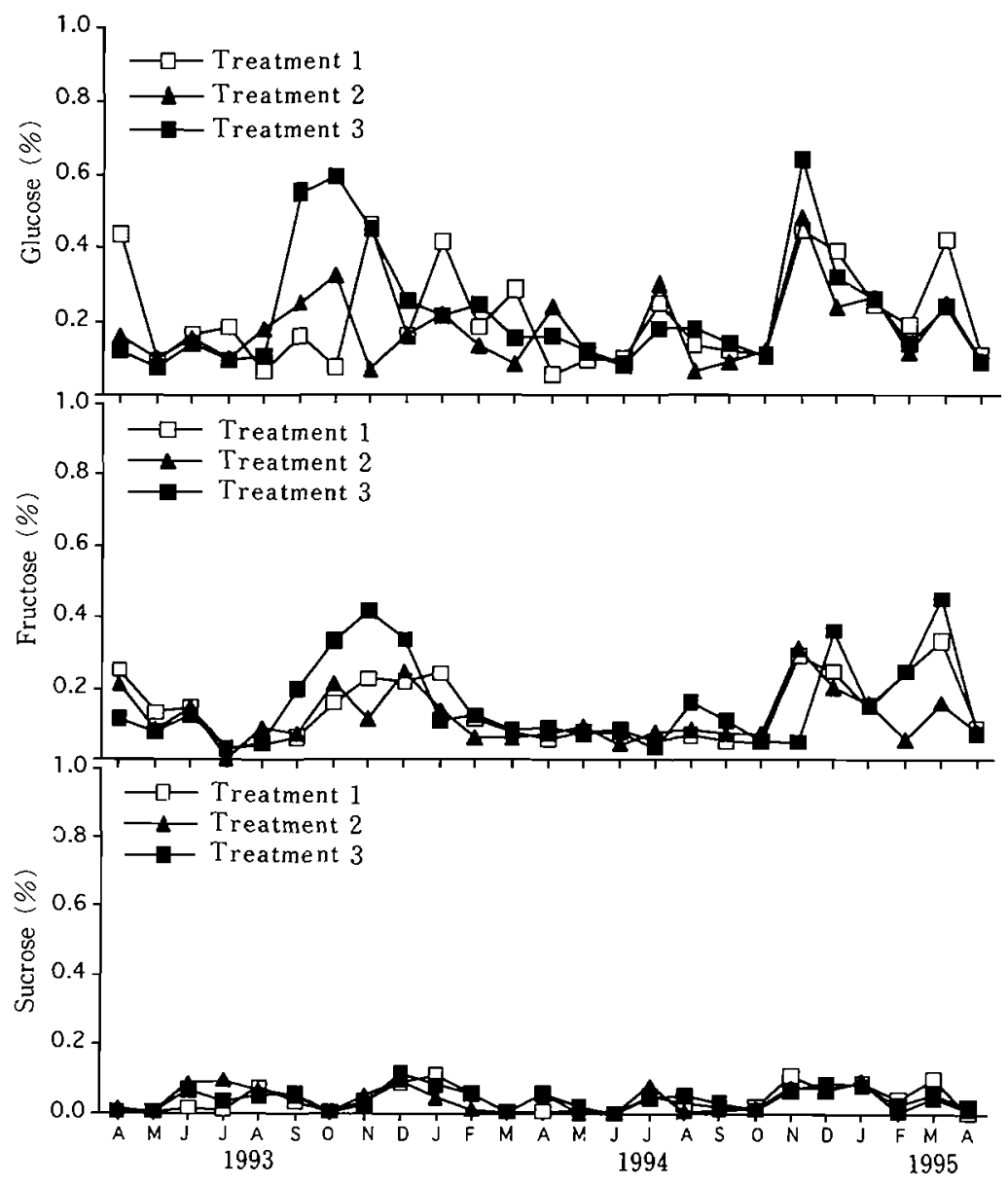

Fig. 7. Seasonal changes in glucose, fructose and sucrose content in shoot of Japanese pear trees grown under different treatments during 1993 to 1995.

what different from 1993. In that sorbitol content which is the main sugar alcohol, increased during growing period as compared to the 1993 level (Figs. 6 and 7).

The trends of total sugar and starch contents follow an inverse pattern suggesting an interconversion. When growth resumed, total sugar contents decreased while starch increased; during winter, sugar content in the shoot was highest while starch content was at a minimum level (Fig. 6).

\section{Discussion}

Unlike homeothermic animals, the plants are unable to maintain their cells and tissues at a constant optimum temperature. Their growth and metabolism are, therefore, profoundly affected by changes in environment temperature (Fitter and Hay, 1987). In our present study, the same pear trees were exposed to high temperature during autumn through spring for 3 consecutive seasons and observation was made on tree vigor as judged by shoot length, budbreak rate and flowering. When the high temperature treatments were initiated in 1992, the treatments were started in July (Treatment 1), September (Treatment 2), and November (Treatment 3). Shoot growth during summer was more vigorous in the trees of Treatment 1 reflecting warmer climate, particularly, at night. Shoots on trees of the Treatment 1 , which were kept warmer starting from July stopped growing and become dormant in October. This in - 
dicates that short day-length is mainly responsible for the induction of dormancy although lower temperature during autumn exerts a supplemental effect (Krug, 1991).

In the spring of 1993 the trees exposed to higher temperature for a longer period during autumn, showed less vigorous shoot growth. Thus, the trees of Treatment 1 were least vigorous followed by those of Treatment 2 and then Treatment 3 . The trees of Treatment 1 also exhibited a lower sprouting rate of both flower and vegetative buds, and delayed and prolonged flowering. Similar results were obtained in 1994 and 1995. Shoot growth in all the treatments became less vigorous after the 2nd and 3rd years. In particular, trees of Treatment 1 showed a poor shoot growth although their transfer date to the greenhouse was delayed to early September in 1993 and 1994. The ETA of the different treatments including the winter months is about two times greater than the ETA of trees in the open field. In 1992, after transferring the trees of Treatment 1 into the greenhouse, the higher temperature and higher effective temperature induced more vegetative growth of the trees than that in Treatment 2 and 3. However, high temperatures during winter of $1992 \sim 1993$ resulted in poor tree growth in 1993 which persisted into 1994 and 1995; the effect became progressively worse with time. This ETA produced differences in shoot growth and reproductive characteristics among the treatments. Martinez (1994) reported that heat in late summer inside the greenhouse can also cause heat stress which limits growth.

When chilling units (CU) are calculated using $7.2{ }^{\circ} \mathrm{C}$ as the maximum effective temperature, trees of Treatment 1 and 2 received $0 \mathrm{CU}$ while those of Treatment 3 received $80 \mathrm{CU}$ during the autumn of 1993 and spring of 1994. Couvillon (1995) demonstrated that $8{ }^{\circ} \mathrm{C}$ is the most effective temperature to break dormancy and that exposure to $12{ }^{\circ} \mathrm{C}$ is also effective although less so than 8 ${ }^{\circ} \mathrm{C}$. Asano and Okuno (1990) showed that in 'Kosui' and 'Hosui' pears, temperatures between $10.1^{\circ}$ and $12{ }^{\circ} \mathrm{C}$ contribute $0.6 \mathrm{CU}$ while that under $10^{\circ} \mathrm{C}$ accumulate $1 \mathrm{CU}$.

Our study shows that the trees of Treatment 3 sprouted at a higher rate but much slower than those in the open field (data not shown). This may be because the outside minimum air temperature reached $10^{\circ} \sim 12{ }^{\circ} \mathrm{C}$ during September and Novem. ber. That some buds on trees of Treatment 1 sprouted suggests that $12{ }^{\circ} \mathrm{C}$ may contribute toward breaking of dormancy.

Differences in shoot growth and other phenological changes were associated with the lack of winter chilling instead of high summer temperature. That indicates that the lack of winter chilling seem to affect trees more adversely than does prolonged summer heat during our experimental years.

In the northern highlands of Thailand maximum and minimum temperatures during summer growing season are similar to those in Japan, but their winter temperature is rather high, minimum rarely going below $10{ }^{\circ} \mathrm{C}$. These conditions seems to be more or less similar to the growing condition of the trees in Treatment 2 and 3 , under which our Japanese pear trees grew fairly well the first year. However, the trees in all treatments became less and less vigorous when warmer climate in winter prevailed every year. One reason for this decline is that the trees were grown in pots and the root temperature of these trees might have been high. Young (1995) showed that low root temperature is effective in breaking dormancy.

Pollen germination of the flowers of Treatment 1 to 3 was considerably poorer than those of the open field. Optimum temperature for pollen germination of Japanese pear is under $20{ }^{\circ} \mathrm{C}$ (Rohitha and Klinac, 1994); the temperature in the green. house during flowering was supraoptimum. In comparing the pollen germination of the trees of Treatment 1 to 3 which underwent the same high temperature, pollen germination was the best in Treatment 3 , followed by of Treatment 2 ; that of Treatment 1 was the poorest. This trend tended to parallel those of shoot growth and bud sprouting which indicates that the decline of tree vigor lows the flower quality.

Changes in starch and sugars in shoots as shown in this study are in agreement with others dealing with dormancy (Cappiello and Kling, 1994). The carbohydrate change is closely related to the active growth of the fruit tree (Kaiser and Wolstenholme, 1994), the more vigorous tree accumulating more carbohydrates (Gaudillere et al., 1992). Sorbitol and other sugars which were high during dormancy and decreased just before and during budbreak. The starch trend was inverse to 
that of sugars. Generally, starch and sugar contents tended to be higher in trees of Treatment 3 which substantiates that trees receiving less chilling units accumulate less carbohydrates. This may explain the inferior shoot growth in trees of Treatment 1 .

Lin (1986) and Erez (1987) demonstrated that hydrogen cyanamide and other chemicals can break dormancy. The research should be repeated for successive years on Japanese pears to evaluate the effects of these chemicals on tree vigor and carbohydrate contents. Furthermore, the breeding programs to obtain heat-tolerant temperate zone fruit were established in many areas (Dennis, 1987). The integration of these researches will be needed to allow the cultivation of temperate zone fruit trees in tropical and subtropical areas.

\section{Literature Cited}

Asano, S. and T. Okuno. 1990. Period of breaking the rest and the quantity of chilling requirement of 'Kosui' and 'Hosui' Japanese pear. Bull. Saitama Hort. Exp. Sta. No. $17: 41-46$.

Cappiello, P. E. and G. J. Kling. 1994. Changes in growth regulator and carbohydrate levels in roots and shoot tips of Comus sericea during cold storage and emergence from dormancy. J. Amer. Soc. Hort. Sci. 119: 785-788.

Couvillon, G. A. 1995. Temperature and stress effects on rest in fruit trees: A review. Acta Hortic. 395 : 11-19.

Dennis, Jr., F. G. 1987. Producing temperate-zone fruits at low latitudes: An overview. HortScience $22: 1226-1227$.

Erez, A. 1987. Chemical control of budbreak. HortScience $22: 1240-1243$.

Fitter, A. H. and R. K. M. Hay. 1987. Environmental physiology of plants. 2ed. Academic Press Ltd., England.

Gaudillere, J-P., A. Moing and F. Carbonne. 1992.
Vigour and non-structural carbohydrates in young prune trees. Scientia Hortic. 51 : 197-211.

Gemma, H., K. Uchino, M. Fukushima and C. Oogaki. 1990. Acclimation of Japanese pear 'Kosui' under warm temperature during early growing period in a vinyl house. Acta Hortic. 279:259-268.

Keiser, C. and B. N. Wolstenholme. 1994. Aspects of delayed harvest of 'Hass' avocado (Persea america. na Mill.) fruit in a cool subtropical climate. II. Fruit size, phenology and whole-tree starch cy. cling. J. Hort. Sci. $69: 447-457$.

Krug, H. 1991. Changes in the activity of rhubarb (Rheum rhaponticum $\times$ rhabarbarum) and its significance for production and forcing. Gartenbauwissenchaft 56:93-98.

Lin, C. H. 1986. Production of temperate zone fruits in Taiwan and studies on dormancy breaking. FFTC book series no. 34, Taiwan, Rep. of China. p. 44-52.

Martinez, P. F. 1994. The influence of environmental conditions of mild winter climate on the physiological behavior of protected crops. Acta Hortic. 357: 29-48.

Rakngan, J., H. Gemma and S. Iwahori. 1995. Flower bud formation in Japanese pears trees under adverse conditions and effects of some growth regulators. Japan. J. Trop. Agr. $39: 1-6$.

Richardson, E. A., S. D. Seeley and D. R. Walker. 1974. A model for estimating the completion of rest for 'Redhaven' and 'Elberta' peach trees. HortScience $9: 331-332$.

Rohitha, B. H. and D. J. Klinac. 1994. Some observations on the influence of temperature on the germination of pollen on excised nashi (Pyrus serotina Rehder var. culta Rehder) flowers. N. Z. J. Crop and Hort. Sci. $22: 339-342$.

Subhadrabandhu, S. 1988. Fruit crop production under highland environment of northern Thailand. Kasetsart J. (Social Sci.). 9: 197-205.

Young, E., T. K. Dautlick and R. D. Belding. 1995. Respiratory changes during dormancy breaking of apple trees. Acta Hortic. 395 : 21-33. 
高温不良環境下で育てたニホンナシの生態と樹体内炭水化物の変化

\author{
Jaturaporn Rakngan・弦間 洋・岩堀修一 \\ 筑波大学農林学系 305 茨城県つくば市
}

\begin{abstract}
摘要
ニホンナシ品種“幸水”の 6 年生鉢植え樹を種々の時 期に連続高温環境下（最低温 $7.2^{\circ} \mathrm{C}$ 以上に保った室 温）に移し，3年間その影響を調べた。初年度に扔い ては 7 月および 9 月に高温に移した区では 11 月に移 した区の樹よりも新梢の生長は旺盛であった。しかし, 冬期の低温不足のため翌年の新梢生長は，前年に早く 高温処理した樹ほど劣った．11月に移した区は春の 萌芽や開花の数も多く，その時期も早く斉一で結実も

得られた．開花した花の花粉の発芽率も 3 年間とも， 11 月に移した区で最も成績がよい傾向を示した。

樹体内の炭水化物の変化をみると, 秋の休眠直前か らの糖含量は增加して，デンプン含量は減少した．春 に樹の生長が開始すると糖は隇少し，デンプンが増加 した１1月に高温に移され，従って低温を受ける期 間の長かった樹では，デンプン，糖含量とも高い傾向 を示した。
\end{abstract} よかった， 2 年目， 3 年目においても，同様の結果が 